\title{
Risk of cytomegalovirus reactivation in patients with immune-mediated inflammatory diseases undergoing biologic treatment: a real matter?
}

\author{
J. Mencarini ${ }^{1}$, M. Spinicci ${ }^{1}$, F. Bartalesi ${ }^{2}$ \\ 1 Infectious Diseases Unit, University of Florence; \\ ${ }^{2}$ Infectious and Tropical Diseases Division, Careggi Hospital, Florence, Italy
}

\section{SUMMARY}

The use of biological agents has grown exponentially in immune-mediated inflammatory diseases (IMID), often achieving a good control of disease progression and improving patients' quality of life. However, their use resulted in an increased risk of adverse events, including reactivation of chronic/latent infectious diseases. As for the risk of Cytomegalovirus (CMV) reactivation, very few data are available. We reviewed the literature reporting cases of CMV infection in IMID patients during biological therapy. Although the risk of CMV reactivation cannot be excluded, we concluded that there is no evidence to warrant CMV screening before starting a biological agent.

Key words: Cytomegalovirus; screening; biological agents; inflammatory diseases

\section{INTRODUCTION}

Tn rheumatic diseases, such as rheumatoid arthritis (RA), psoriatic arthritis (PsA) and ankylosing spondylitis (AS) and in other immune-mediated inflammatory diseases (IMID), such as chronic inflammatory bowel diseases (IBD) or multiple sclerosis (MS), biological treatments have been largely employed.

Their use has resulted in an increased risk of new infectious events and reactivation of chronic/latent infectious diseases. In other immunosuppression conditions (solid organ transplant, Acquired Immune Deficiency Syndrome- AIDS), the risk of viral infections reactivation is well known. This problem seems to be less evident in IMID patients who assume anti-tumour necrosis factor- $\alpha$ (anti-TNF- $\alpha$ ) or other biologic therapies, although reactivations of Varicella-Zoster virus (VZV) and John Cunningham virus (JC) have been widely reported. As for CMV reactivation, very few data are available in patients with IMID un- dergoing biological treatment. Before starting biological therapy the screening for CMV infection is not recommended in the evidence-based consensus by the European Crohn's and Colitis Organization (1), by the European League Against Rheumatism (EULAR) (2) and by the Italian Society for Rheumatology (3).

The aim of this work is to update the literature evidence on the risk of CMV reactivation in IMID patients, in order to understand if screening before biologic therapy is necessary.

\section{MATERIALS AND METHODS}

A review of Pubmed and indexed literature on CMV and IMID was carried out. The following search terms were used in PubMed (http://www.ncbi.nlm.nih.gov/ pubmed/): Cytomegalovirus, anti-TNF, rheumatoid arthritis, psoriatic arthritis, ankylosing spondylitis, inflammatory bowel diseases. We included case report or case series until April 2015. 


\section{RESULTS}

In the 3-year prospective French RATIO registry, including 57,711 patient/year undergoing biologic therapy for a broad spectrum of IMID, Salmon-Ceron et al. (4) described 3 disseminated CMV infections in Crohn's disease.

It is not clear if the cases were primary infections or reactivations, but one patient was HIV (human immunodeficiency virus) positive and had a Pneumocystis pneumonia. During immunomodulating therapy for IBD, severe CMV reactivations are rarely reported and only in one case with poor outcome (5).

In the other case reports, the antiviral treat- ment and the discontinuation of the immunosuppressive agents were associated with clinical improvement (6-9). The role of CMV in the exacerbations of IBD remains a topic of ongoing debate. CMV colitis is rare in patients with Crohn's disease or mild to moderate ulcerative colitis, but CMV reactivation can be detected in about $30 \%$ of patients with severe and/or steroidrefractory ulcerative colitis, with remission rates of $67-100 \%$ following antiviral therapy with intravenous ganciclovir. However, despite an inconclusive knowledge, testing for CMV reactivation should be performed in presence of refractory colitis and, in case of a positive result, antiviral therapy should be started (10).

Table I - CMV infections occurred during biological therapy in IMID patients.

\begin{tabular}{|c|c|c|c|c|c|c|}
\hline Author & Year & IMID & $\begin{array}{l}\text { Treatment at the time } \\
\text { of CMV infection }\end{array}$ & $\begin{array}{l}\text { Primary infection }(P) \\
\text { or reactivation }(R)\end{array}$ & Trattamento & Esito \\
\hline $\begin{array}{l}\text { Salmon Ceron D } \\
\text { et al. (4) }\end{array}$ & 2011 & 3 Crohn's disease & Infliximab & $\mathrm{NR}$ & NR & $\begin{array}{l}\text { Improvement } \\
1 \text { lost at follow up }\end{array}$ \\
\hline $\begin{array}{l}\text { Salmon Ceron D } \\
\text { et al. (4) }\end{array}$ & 2011 & RA & Infliximab & NR & NR & Improvement \\
\hline $\begin{array}{l}\text { Pickering } \mathrm{O} \text { et } \\
\text { al. (5) }\end{array}$ & 2009 & $\begin{array}{l}\text { Crohn's disease } \\
\text { and sickle cell } \\
\text { anemia }\end{array}$ & $\begin{array}{l}\text { Infliximab } \\
\text { 6-mercaptopurine }\end{array}$ & (lgG e lgM pos) & Ganciclovir DIT & Death \\
\hline Charles et al. (6) & 2010 & Ulcerative colitis & $\begin{array}{l}\text { Adalimumab } \\
\text { Azathioprine } \\
\text { Prednisone }\end{array}$ & $\mathrm{R}$ & Ganciclovir DIT & Surgery (colectomy) \\
\hline Mizuta M et al. (7) & 2005 & Crohn's disease & $\begin{array}{l}\text { Infliximab prednisone } \\
\text { 6-mercaptopurine }\end{array}$ & (IgG e lgM pos) & Ganciclovir & Improvement \\
\hline $\begin{array}{l}\text { Kohara MM et } \\
\text { al. (8) }\end{array}$ & 2006 & Crohn's disease & $\begin{array}{l}\text { Infliximab } \\
\text { 6-mercaptopurine }\end{array}$ & (lgG e lgM pos) & $\begin{array}{l}\text { Ganciclovir, } \\
\text { splenectomy }\end{array}$ & Improvement \\
\hline $\begin{array}{l}\text { Helbling D et } \\
\text { al. (9) }\end{array}$ & 2002 & Crohn's disease & $\begin{array}{l}\text { Infliximab } \\
\text { Azathioprine } \\
\text { Corticosteroids }\end{array}$ & $P$ & $\begin{array}{l}\text { Foscarnet/ } \\
\text { Ganciclovir DIT }\end{array}$ & Improvement \\
\hline $\begin{array}{l}\text { Haerter G et al. } \\
\text { (11) }\end{array}$ & 2004 & RA & $\begin{array}{l}\text { Infliximab } \\
\text { Cyclophosphamide } \\
\text { Azathioprine }\end{array}$ & $\mathrm{R}$ & $\begin{array}{l}\text { Ganciclovir/ } \\
\text { valganciclovir }\end{array}$ & $\begin{array}{l}\text { Initial relapse, then } \\
\text { improvement }\end{array}$ \\
\hline $\begin{array}{l}\text { Petersen B et } \\
\text { al. (12) }\end{array}$ & 2008 & PsA & Etanercept & $P$ & DIT & Improvement \\
\hline $\begin{array}{l}\text { Petersen B et } \\
\text { al. (12) }\end{array}$ & 2008 & PsA & Efalizumab & NR & DIT & Improvement \\
\hline Vallet $\mathrm{H}$ et al. (14) & 2011 & RA & Rituximab & NR & $\begin{array}{l}\text { Ganciclovir/ } \\
\text { Valganciclovir } \\
\text { IVIG }\end{array}$ & Improvement \\
\hline Sari I et al. (15) & 2008 & Behcet's disease & Infliximab & $\mathrm{R}$ & Ganciclovir DIT & Improvement \\
\hline
\end{tabular}

IMID, immune-mediated inflammatory diseases; RA, rheumatoid arthritis; PsA, psoriatic arthritis; NR, not reported; DIT, discontinuation of immunomodulating therapy; IVIG, intravenous immunoglobulin.

Note: Reference 13 not included in the table due to the absence of available data on treatment and outcome. 
Referring to the rheumatic diseases patients, the French RATIO registry reported one case with rash and fever due to CMV in RA (primary infection or reactivation?) (4). In other reported cases (11-15), the discontinuation of immunomodulating therapy led to the improvement of the patients' conditions, with or without concomitant antiviral therapy.

Haerter et al. (11) described a case of retinitis in a patient with RA with an impaired cellular immune state, probably due to treatment with cyclophosphamide and azathioprine. We found one report describing two CMV infections in patients affected by psoriasis during anti-TNF- $\alpha$ therapy (12). In case of the novel therapies for RA, like Janus Kinase (JAK) inhibitors (tofacitinib), an analysis to determine the rate of infections reported 6 cases of CMV infection, but it's not clear if the clinical presentation was severe neither if it was a primary infection or a reactivation (13). In Table I, we summarize the cases of CMV infection reported during biological therapy in IMID patients.

\section{DISCUSSION AND CONCLUSIONS}

Our brief literature review is consistent with the hypothesis that, during antiTNF- $\alpha$ therapy in IMID patients, CMV reactivation is possible, although the risk is very low.

The clinical reports did not describe clearly if infection was primary or a reactivation. As a result, we cannot recommend antiCMV antibodies detection or CMV-DNA testing in the infectious diseases screening applied to patients before starting biological treatment. This recommendation is also supported by the fact that the pre-emptive therapy would be generally not indicated, with the exception of some groups of immunocompromised patients (hematopoietic stem cell transplantation or acquired immunodeficiency syndrome).

On the other hand, it is important to underline that, in patients receiving biological drugs, presenting fever of unknown origin, particularly if associated with rash, hepati- tis or visual field defects, clinicians should be aware of the risk of CMV reactivation and specific diagnostic tools should be performed.

\section{Conflict of interest. none}

\section{REFERENCES}

1. Rahier JF, Magro F, Abreu C, et al. Second European evidence-based consensus on the prevention, diagnosis and management of opportunistic infections in inflammatory bowel disease. J Crohns Colitis. 2014; 8: 443-68.

2. Gossec L, Smolen JS, Ramiro S, et al. European League Against Rheumatism (EULAR) recommendations for the management of psoriatic arthritis with pharmacological therapies: 2015 update. Ann Rheum Dis. 2016; 75: 499510.

3. Salvarani C, Pipitone N, Marchesoni A, et al. Recommendations for the use of biologic therapy in the treatment of psoriatic arthritis: update from the Italian Society for Rheumatology. Clin Exp Rheumatol. 2011; (Suppl. 66): $28-41$.

4. Salmon-Ceron D, Tubach F, Lortholary O, et al. Drug specific risk of non-tuberculosis opportunistic infections in patients receiving anti-TNF therapy reported to the 3-year prospective French RATIO registry. Ann Rheum Dis. 2011; 70: 616-23.

5. Pickering O, Weinstein T, Rubin LG. Fatal disseminated cytomegalovirus infection associated with infliximab and 6-mercaptopurine therapy in a child with Crohn disease. Pediatr Infect Dis J. 2009; 28: 556.

6. Charles P, Ackermann F, Burdy G, et al. Cytomegalovirus colitis complicating ulcerative colitis treated with adalimumab. Scand J Gastroenterol. 2010; 45: 509-10.

7. Mizuta M, Schuster MG. Cytomegalovirus hepatitis associated with use of anti-tumor necrosis factor- $\alpha$ antibody. Clin Infect Dis. 2005; 40: 1070-1.

8. Kohara MM, Blum RN. Cytomegalovirus ileitis and hemophagocytic syndrome associated with use of anti-tumor necrosis factor- $\alpha$ antibody. Clin Infect Dis. 2006; 42: 733-4.

9. Helbling D, Breitbach TH, Krause M. Disseminated cytomegalovirus infection in Crohn's disease following anti-tumour necrosis factor therapy. Eur J Gastroenterol Hepatol. 2002; 14: 1393-5.

10. Lawlor D, Moss AC. Cytomegalovirus in inflammatory bowel disease: pathogen or innocent bystander? Inflamm Bowel Dis. 2010; 16: 1620-7.

11. Haerter G, Manfras BJ, De Jong-Hesse Y, et 
al. Cytomegalovirus retinitis in a patient treated with anti-TNF alpha antibody therapy for rheumatoid arthritis. Clin Infect Dis. 2004; 39: e88-94.

12. Petersen B, Lorentzen H. CMV complicating biological immunosoppressive therapy in two patients with psoriasis receiving treatment with etanercept or efalizumab. Acta Derm Venereol. 2008; 88: 523-4.

13. Cohen S, Radominsky SC, Gomez-Reino JJ, et al. Analysis of infections and all-cause mortality in phase II, phase III, and long-term ex- tension studies of tofacitinib in patients with rheumatoid arthritis. Arthritis Rheum. 2014; 66: 2924-37.

14. Vallet H, Houitte R, Azria A, Mariette X. Cytomegalovirus colitis and hypo-IgG after rituximab therapy for rheumatoid arthritis. J Rheumatol. 2011; 38: 965-6.

15. Sari I, Birlik M, Gonen C, et al. Cytomegalovirus colitis in a patient with Behcet's disease receiving tumor necrosis factor alpha inhibitory treatment. World J Gastroenterol. 2008; 14: 2912-4. 